\title{
THE POWER OF FAN COMMUNITIES: AN OVERVIEW OF FANSUBBING IN BRAZIL
}

\author{
Bianca Bold
}

Media fans are consumers who also produce, readers who also write, spectators who also participate.

HENRY JENKINS

\section{Introduction}

In the age of participatory culture, fans and consumers are no longer passive receptors of products and services in general. Contemporary consumers of audiovisual media, in particular, do not stand at the very end of the production chain. This new empowered consumer now questions hierarchies and boundaries that were once clearly established between producers and consumers (Mazetti, 2009, p. 2). Supported by all the technology available nowadays, this revolutionary interaction between audiovisual media viewers and products has also been influencing the audiovisual translation market, with much new translated material in countless languages being distributed for free every single day.

This research found its major motivation in two facts: (1) the striking presence of subtitles that are produced by fans and made available free of charge on the internet and (2) the scarcity of scholarly material on the subject, especially of texts addressing the Brazilian market. Although film dialogue is covered under Brazilian copyright law, and unauthorized transcriptions are considered an infringement (Mizukami et al., 2011, p. 266), the discussion of legal issues involved in the fansubbing activity is beyond the scope of this paper. The article begins with a brief discussion on the emergence of so-called "prosumers", user-generated content, and fan translation, and goes on to address the inception and evolution of fansubbing and the rationale underlying this activity. The focus then turns to the Brazilian fansubbing phenomenon, with topics that range from the current organization of the local fansubbing community and workflow to common fansubbing 
BOLD - The Power of Fan Communities...

practices and standards, and how these practices and standards compare to subtitling carried out by professional Brazilian translators.

\section{"Prosumers", user-generated content, and fan translation}

Back in 1980, Alvin Toffler coined the portmanteau "prosumer" initially to describe people who create goods, services, or experiences for their "own use or satisfaction, rather than for sale or exchange" (Toffler \& Toffler, 2006, p. 153). As a result of the changes society has gone through, a broader application of this term was recognized over two and half decades later: "today [in 2006], given the shrinkage of the world because of advances in transportation, communications and I.T. [Information Technology], the notion of prosuming can include unpaid work to create value to share with strangers half a world away" (p. 153).

These advances have also allowed for the exponential growth of fan cultures and related activities of various sorts. The lives of consumers and fans have been impacted by the greater accessibility to numerous means of interacting online and sharing culture. Multitudes of fans are now able to congregate and easily exchange materials, opinions, ideas, and information regardless of where they live. Fan communities have been growing and gaining greater online and offline visibility. As Luis Pérez González (2007, p. 275) contends, "the marriage between fandom and technology has started to shape the creation and distribution of audiovisual products in general, not just their translation". It has become easier for modern consumers to engage in a wide range of collaborative projects related to their idols or admired products and to create what has come to be known as "user-generated content".

Different forms of user-generated content, both original and translated, abound on the Web, not all being necessarily undertaken by fans. With respect to translation, different terms have been used by researchers. Donald A. DePalma and Nataly Kelly (2008) refer to this practice as "user-translated content" and "community translation", Minako O'Hagan (2009, p. 97) adopts the term "user-generated translation" and describes it as a wide variety of translation carried out by self-selected individuals who, driven by their interest in the content, act as mediators of linguistically inaccessible materials. 
It is interesting to note that user-generated content designed by fans does not necessarily involve only translation or audiovisual media. This activity can encompass a variety of products that attempt to recreate the original, give it continuity or visibility, among other goals. These creations usually result from the interaction of like-minded, often tech-savvy fans, who generally join forces to collaborate for a common cause, "within the supposedly 'free' space of leisure practices" (Hills, 2002, p. 14), and expect no monetary compensation.

Below are some of the most common of these products, both user-generated content and user-generated translation-lists that are neither exclusive nor exhaustive.

\section{○ User-generated content by fans (not involving interlingual translation):}

- Fan sequels can refer either to fan films (or fanvideos), i.e. amateur videos inspired in original products varying from novels and comic books to a range of audiovisual media, or fangames, amateur video game sequels based on fans' favourite video games.

- Fan fiction is similar to the above but involves the creation of fictional works, from short stories to novels or films. Its short form, fan fic, is also widely used.

- Fanzine derives from the blend of "fan" and "magazine" and refers to magazines written, edited, and distributed by fans.

- Fansites are websites developed and maintained by fans to promote fan community interaction and to disseminate information on the main topic and various forms of fan arts.

- Reviews of movies, video games, books, TV shows, concerts, and various other types of products/services are also commonly written by fans who want to share their own critical accounts and analyses. These texts are often posted on blogs, social media platforms, magazines, newspapers, fansites, fanzines, or databases such as IMDb (Internet Movie Database: www.imdb.com).

\section{$\bigcirc$ User-generated translation by fans (involving interlingual translation):}

- Fansubbing is the translation and subtitling of audiovisual materials. 
- Fandubbing is the translation and dubbing of audiovisual media.

- Scanlation derives from the combination of "scanning" and "translation" and is used mostly for comic books: fans scan the original product, translate it, and manipulate the images to insert the new text.

- Fan translation and localization of video games is performed by fans or groups of fans who not only translate but also, and above all, have excellent computer skills. The aim is to extract the relevant text from the binary ROM (read-only memory) image of the video game and replace it with its translated and localized version (O’Hagan, 2009, p. 107-108).

- Fans have also been dedicating time to the translation of literary works before the commercial translations of these products reach the market.

\section{The fansubbing phenomenon worldwide}

Each of the practices described in the previous section has its idiosyncrasies. In recent years, some have been attracting the attention of Media and Cultural Studies, as well as that of the Translation Studies and Audiovisual Translation communities. In 2005, Jorge Díaz Cintas (2005, p. 11) claimed that the new developments brought by fansubbing practices would be "prime candidates for future scholarly attention", since audiovisual media consumers were bound to increase their power in the near future. When discussing anime fansubbing later on, Pérez González (2007, p. 275) echoed Díaz Cintas's idea when stating that, "[i]n a globally connected information environment, fans (agents of chaos) have brought about new subtitling practices (small variations in the initial conditions of the system) whose future impact on mainstream subtitling conventions should not be minimised". The author concluded that the impact of this phenomenon was bound to receive more attention both from Audiovisual Translation and Media Studies scholars, but that fansubbing was still (as of the date of his study) "under-represented in audiovisual translation scholarship" (p. 276).

Although the literature is not yet vast, the terminology related to this activity is varied. "Fansubbing" and other terms formed with different suffixes to designate the product and the producer- "fansub(s)" and "fansubber", respectively-are the most commonly used. Naturally, the verb "to fansub" has been adopted as well. There are also 
BOLD - The Power of Fan Communities...

occurrences of various other terms and expressions, most of which are formed with words such as "fan", "amateur", and "internet".

Referring to the activity, besides “fansubbing” (Díaz Cintas, 2005; Ferrer Simó, 2005; Kayahara, 2005; Leonard, 2005; Díaz Cintas \& Muñoz Sánchez, 2006;

\& Remael, 2007; Mazetti, 2009; Franco, 2010; Ramos, 2010; Casarini, 2011a; Di Giovanni \& Spoletti, 2011), there are "subtitling 'by fans for fans" (Díaz Cintas, 2005;

\& Remael, 2007; Díaz Cintas, 2009), “fan(-)subtitling” (Ferrer Simó, 2005), “amateur subtitling” (Díaz Cintas \& Muñoz Sánchez, 2006; Pérez González, 2007; Bogucki, 2009), “amateur fansubbing” (Casarini, 2011a), "subbing” (Díaz Cintas, 2005; ～～\& Remael, 2007; Díaz Cintas, 2009), "legendagem pirata" (equivalent to "pirate subtitling"; Feitosa, 2009), "fansubtitulación" (equivalent to "fan-subtitling"; Ferrer Simó, 2005), "fan-based subtitling” (Mizukami et al., 2011), “internet subtitling” ( \& Remael, 2007), and "home-made subtitling” (Bogucki, 2009).

Referring to the products (either subtitle text files or videos with embedded, synchronized subtitles), one finds "fansub" (Ferrer Simó, 2005; Díaz Cintas, 2005; Leonard, 2005; Díaz Cintas \& Muñoz Sánchez, 2006; $\quad$ \& Remael, 2007; Díaz Cintas, 2009; O'Hagan, 2009; Calazans, 2010; Franco, 2010; Ramos, 2010; Casarini, 2011a; Cho, 2011a), “fan-produced subtitle” (O'Hagan, 2009), "fantitle” (Feitosa, 2009), "legenda de fãa(s) para fãa(s)" (equivalent to "subtitle by fan(s) for fan(s)"; Feitosa, 2009; Ramos, 2010), "fan-made subtitle" (Feitosa, 2009), "legenda de internet" (equivalent to "internet subtitle"; Miller, 2008), "legenda(s) amadora(s)" (equivalent to "amateur subtitle(s)"; Miller, 2008; Bandeira, 2011), "fan-subtitled video" (Leonard, 2005), “'home-made' caption”, and “amateur caption” (Bogucki, 2009).

Referring to the producers, there are "fansubber" (Ferrer Simó, 2005; Leonard, 2005; Díaz Cintas \& Muñoz Sánchez, 2006; Díaz Cintas, 2009; Ramos, 2010; Casarini, 2011a; Di Giovanni \& Spoletti, 2011), “fansubtitulador" (equivalent to "subtitler-fan"; Ferrer Simó, 2005), "fãa(-)legendista" (equivalent to "subtitler-fan”; Feitosa, 2009; Ramos, 2010), “amateur subtitler" (Di Giovanni \& Spoletti, 2011), “amateur subtitle producer” and "internet subtitler" (Bogucki, 2009), and "legender" (Miller, 2008; Calazans, 2010; Pagano, 2010; Bernardo, 2011; Mizukami et al., 2011)—an interesting Brazilian 
BOLD - The Power of Fan Communities...

neologism, derived from the Portuguese word "legenda" (subtitle) followed by the English suffix “-er".

\section{The rationale and evolution of fansubbing}

The volunteer translation of audiovisual media by fans dates back to the 1980s. Anime fans from the United States of America were engaged in translating and subtitling Japanese audiovisual materials during the VHS (Video Home System) era, as the earliest known fansubbed product is a 1986 copy of Lupin III (Leonard, 2005, p. 301).

The technological developments that have emerged since then are countless and involve the digitalization of videos, great accessibility of Web 2.0, high-speed internet, and mass-scale connectivity on peer-to-peer (P2P) applications. To facilitate the whole subtitling process (and not only for amateurs), there has also been increasingly easier access to a better and wider variety of free high-technology tools, such as multimedia authoring and subtitling software. The creation of programs that compress images to reduce the size of video files is another important part of this equation, as pointed out by María R. Ferrer Simó (2005, p. 28).

All this has changed even more the way viewers and fans of audiovisual products interact with the media and the production chain. In their 2006 article on anime fansubbing, Jorge Díaz Cintas and Pablo Muñoz Sánchez noted that this phenomenon was becoming more widespread and already encompassing other languages and genres (2006, p. 45). Today, many passionate non-Anglophone fans refuse to be left behind when American TV channels release new episodes of their favourite shows. These consumers are not willing to sit back and wait while distributors and producers take weeks, sometimes months, to handle the professional translation of the commercially broadcast shows. This is a point where the power of the "prosumers" comes into play. The unparalleled phenomenon of fansubbing has received extra momentum, and the online collaboration afforded by technology has allowed fans to quickly spread this activity and its products around the globe.

Scholars who have approached fansubbing mention different motivations for this phenomenon. As with regular translation, the primal reason for this type of translation is to

help those who do not speak a given language to access videos in that language. Besides this, there is the rationale brought up by O'Hagan (2009, p. 100): the fans' main motivation 
BOLD - The Power of Fan Communities...

and justification for engaging in fansubbing lie in their desire to compensate for the delay in the production and distribution of the commercial translations. Lukasz Bogucki (2009, p. 57) addresses the fansubbers' ambition to "make a name", i.e. to be known as the first person to subtitle any given famous release. Pérez González (2007, p. 265) points to the failure of commercial subtitles in dealing successfully with the cultural references present in Japanese animation and its idiosyncrasies. Other academics superficially discuss more philosophical motives, such as intervening in the media market seeking to "shape the dynamics of the audiovisual media industries" (Pérez González, 2007, p. 276), and defending the free online distribution of subtitled audiovisual programs (Díaz Cintas, 2005, p. 16). Nevertheless, most scholars (Bogucki, 2009, p. 49; Ferrer Simó, 2005, p. 27; O’Hagan, 2009, p. 100; Pérez González, 2007, p. 275; Díaz Cintas \& Muñoz Sánchez, 2006, p. 44; Díaz Cintas, 2005, p. 16) emphasize that one of the main rationales behind fansubbing is to popularize audiovisual media that are not very well known in the fans' countries, because they are not widely distributed or are sometimes even absent in the market.

The great popularity of Brazilian fansubs seems to be propelled by two major factors: (1) the prestige and acknowledgement that fansubbers and their teams earn as their signed translations circulate on the Web, and (2) "the weakness of Brazilian distribution, which includes broadcasting delays and the limited availability of many categories of legal media goods" (Mizukami et al., 2011, p. 265).

\section{The fansubbing movement in Brazil}

Illustrating the two above-mentioned motivations of the Brazilian fans and other interesting data, Figure 1 shows a screenshot of the most prominent fansubbing website in Brazil today, Legendas.tv (http://legendas.tv). The image was captured on August $2^{\text {nd }}$, 2011, two days after the sixth episode of the fourth season of the TV show True Blood was broadcast in the United States, at 9pm (GMT -4h). On the same date of this screening, July $31^{\text {st }}$, the Brazilian audience was catered to in receiving the fourth True Blood episode of the same season, aired in the United States fifteen days before. The speedy collaboration of no less than eight fans allowed Legendas.tv to post the amateur subtitle files for the latest episode of this show on August $1^{\text {st }}$, at 2:44pm (GMT $\left.-3 \mathrm{~h}\right)$, i.e. less than 24 hours after the 
original broadcast. Between the posting of the subtitles and the screenshot, the files had been downloaded 11,485 times and had been unanimously considered to be of top quality by the 353 users who cared to grade the work.
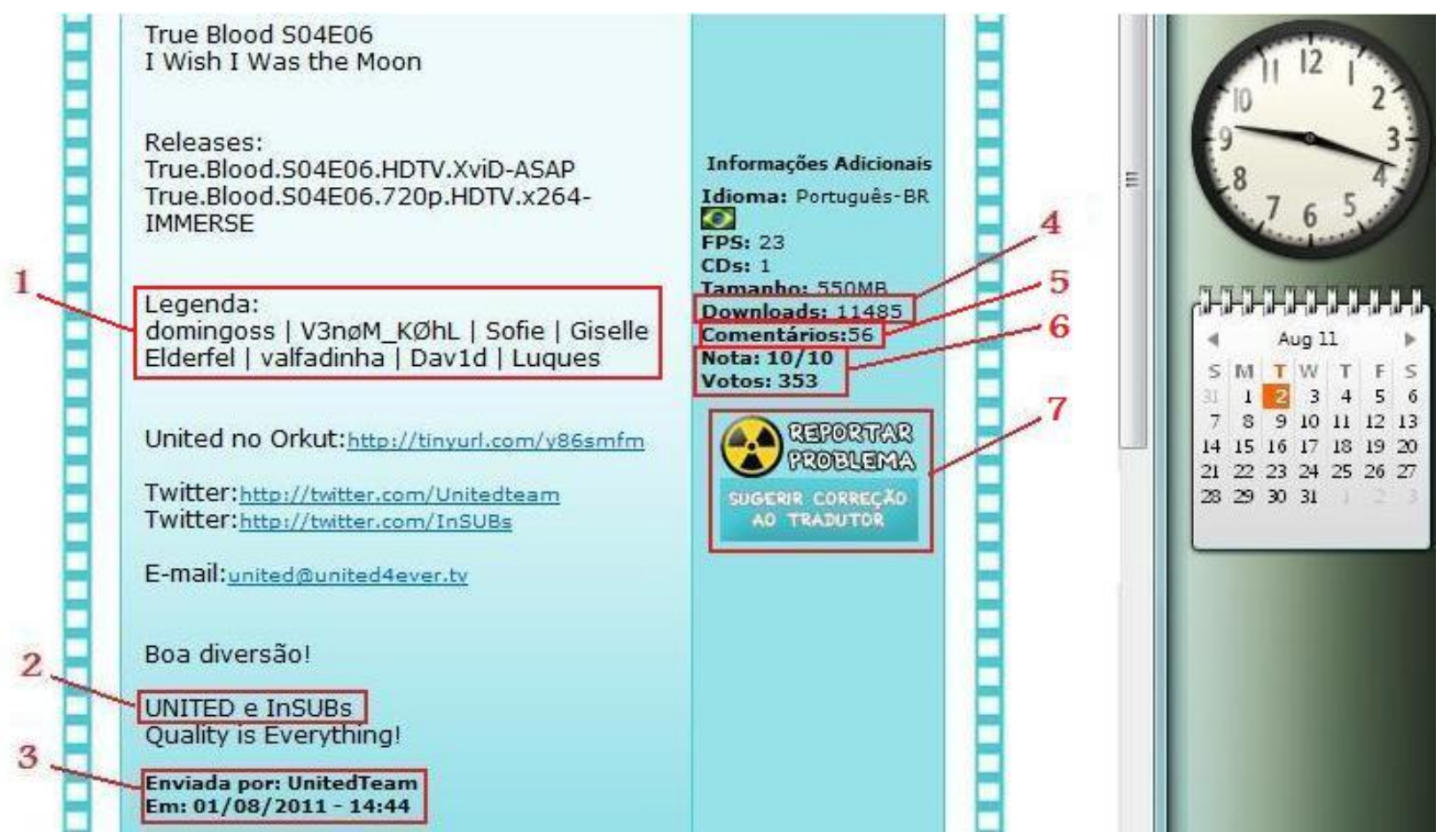

Figure 1 - Screenshot of Legendas.tv on August $2^{\text {nd }}$, at 9:18am (GMT -4h): Download page of the Brazilian fansubs for the True Blood episode aired in the USA on July $31^{\text {st }}$, at $9 \mathrm{pm}$ (GMT $-4 \mathrm{~h}$ ). The highlighted areas show (1) the nicknames of the fans responsible for the fansubbing; (2) the names of the teams to which these fans belong; (3) the date and time the files were posted-August $1^{\text {st }}$, at $2: 44 \mathrm{pm}$ (GMT $\left.-3 \mathrm{~h}\right)$; (4) the total number of downloads $(11,485$, until the screenshot time); (5) the number of comments posted by users - most of which thanking the teams for what they consider good work; (6) how users have graded the quality of the subtitles (10 out of 10) and how many users have graded it (353, until the screenshot time); and (7) an interactive feature of the website through which users can report problems and suggest corrections to the translator.

\section{Brazilian fansubbing networks}

The fansubbing networks in Brazil seem to function in a very organized manner to be able to deal with the extremely short self-imposed deadlines and fulfill the expectations of the fan communities. This is especially true for the translation and distribution of American TV series, a genre that has been attracting more and more the attention of Brazilian audiences ever since the popularization of cable TV in that country. 
Most of the fans involved in the fansubbing process congregate in a variety of online media spaces, Legendas.tv being the most prominent of all. Besides acting as a host website for the subtitles, Legendas.tv also has online forums to foster discussion among users and is responsible for the organization, standardization, and scheduling of the translations. Despite the existence of other somewhat similar websites or blogs, Legendas.tv was chosen to be the main one analyzed in this research because of its popularity and, especially, the role it plays in the imposition of fansubbing standards and practices.

The fansubbing community is divided into groups or teams, which have to be registered with Legendas.tv and comply with the norms and standards created by the website administrators. Very popular shows are referred to as destaques (highlights) and assigned only to well-established groups. According to Mário Henrique Perin Bernardo (2011, p. 18), not all fansubbing groups are in charge of translating highlights, and, to be able to keep this concession, the teams are required to maintain skills such as agility, quality, and responsibility. The prestige factor obviously plays an important role, as highlights are displayed on the homepage of Legendas.tv and carry the name of the respective fansubbing teams (Figure 2). 


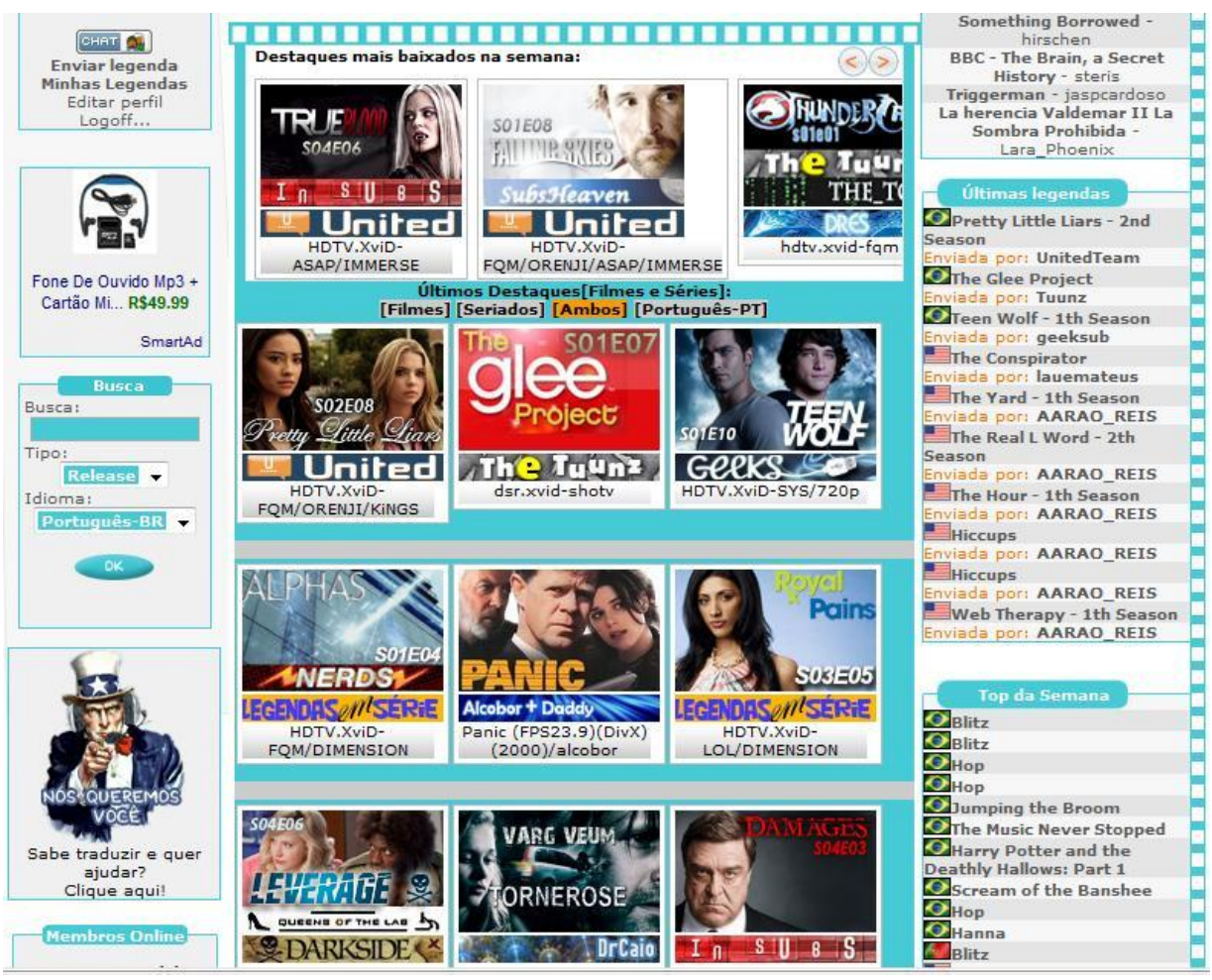

Figure 2 - Screenshot of Legendas.tv on August $2^{\text {nd }}$, with the highlights of the week on the homepage and their respective translation teams.

Most fansubbing teams also have their own websites, whose URLs are often disclosed in their subtitle files and wherever they upload their translations to. However, a quick internet search indicates that Legendas.tv is second to none when it comes to the Brazilian fansubbing distribution network, especially because it hosts the work of countless teams and, as a consequence, gathers virtually all subtitle files of the most popular shows and movies.

\section{Organization of the fansubbing process}

The fansubbing work in Brazil is generally divided among different members of a given fansubbing team. This division of tasks is usually carried out by the so-called administrador da equipe (team administrator). This dedicated member is also often in charge of the general management of the team workflow.

Below are the common steps that seem to be followed by most fansubbing groups in Brazil working with American TV shows: 


\section{(1) Acquisition of the video in English (and often its closed captions)}

A form of pirated video, TV-rips ${ }^{1}$ of American shows are usually available via torrent distribution groups within a few hours after the original airing. Their closed captions (or subtitles for the deaf and hard-of-hearing, SDH) are usually extracted from the original video and made available on the Web almost simultaneously to the video release (Bernardo, 2011, p. 23). Today Brazilian fansubbers often work with rips and SDH as templates. These captions are useful not so much because of their timing (synchrony between audio and video) or spotting (internal and external segmentation of the text), but as an attempt to compensate for the lack of access to official post-production scripts or dialog lists. It is a way fans have found to not rely solely on their comprehension of the foreign audio.

\section{(2) Translation and spotting}

It is common for the Brazilian groups to share the translation of a TV show episode among four or more fansubbers. However, not every fan can translate whatever s/he wants. A given series is usually translated by members of the same group, but it is also common for two groups to join efforts. According to Bernardo (2011, p. 66), translators can be assigned to a particular task by the group administrator, or they can pick their favourite shows, as long as they observe the deadlines and recommendations in the tutorials. Members of the InSUBs team-one among the most active fansubbing groups-explain in their blog that the deadline for translation is normally not more than a day (Equipe InSUBs, 2010).

\section{(3) Synchronization or timing}

The person who synchronizes the subtitles according to the audio is called a syncer or timer (Pérez Gonzáles, 2007, p. 267). This team member is also responsible for adjusting the subtitles to abide by the group's formal standards, i.e. minimum and

\footnotetext{
${ }^{1}$ According to Dictionary.com (http://dictionary.reference.com/browse/rip), the term "rip" is derived from "rip off", i.e. to steal. It means to copy audio or video data from media such as CDs or DVDs and save them as files in a format that is more suitable for computer playback, such as MP3 and DivX.
} 
BOLD - The Power of Fan Communities...

maximum exposition time, and character-per-second ratio (Bernardo, 2011, p. 23). This task might involve changing the spotting of the SDH template.

\section{(4) Editing}

The reviser/editor is usually a senior member of the fansubbing group who merges the parts of subtitles that were translated by other team members and revises the whole work, in terms of both synchronization and translation, to make it cohesive and coherent (Bernardo, 2011, p. 23). S/he is also responsible for correcting mistakes related to adaptation, fluency, and reading time (Equipe InSUBs, 2010). In other words, this member is in charge of the overall quality assurance and also tries to ensure that the final product appears seamless, despite having been created by so many hands.

\section{(5) Resynchronization}

It seems this step is not carried out by all fansubbing groups. However, the InSUBs team has its own rule: subtitles can only be posted with its $720 \mathrm{p}$ resync (Equipe InSUBs, 2010), i.e. the synchronization is adjusted to the high-definition television release (HDTV). Still according to this team, most resyncs only take ten minutes, whereas a few videos need to be resynchronized line by line due to frame-rate differences. This step is also done individually whenever there is a new release of the video, i.e. DVD-rips, Blu-ray-rips, and so on.

\section{(6) Upload and distribution}

The team administrator is usually the one responsible for uploading the text file(s) to the team's website or blog, or contacting the administrator of the website, blog, or P2P environment (such as Legendas.tv) where the subtitles are made available to the public. This leads us to another important and very common feature of the Brazilian fansubbing world: most of these websites do not host or link to pirated videos with embedded subtitles. Rather, they limit the distribution to fansubs in the

form of downloadable synchronized text files, such as .SRT and .SUB. The way these files are named clearly indicates for which release the translation was 
prepared, leaving it up to viewers to find the respective videos-not a hard task for those familiar with the internet, especially P2P platforms. The subtitle files are then easily integrated with the video files on most software used for playing common video formats. As Bernardo (2011, p. 17) explains, this practice is known as "softsubbing" and is different from "hardsubbing", a method by which the subtitles are attached to the image to form a single file.

Steps two to four resemble the common commercial subtitling process in Brazil. However, although professional subtitlers usually belong to teams, there is normally a single person in charge of the translation proper, mainly because of concerns with coherence and consistency. The rest of the professional team is in charge of editing and various technical aspects of subtitling.

From the conversations observed in online forums, most Brazilian fansubbers seem to work with the Subtitle Workshop software. This freeware program designed for subtitling is not only highly functional, but also very popular among professional translators in Brazil. If the subtitler has the video in a digital format, which is always the case with fansubbers, s/he can use the software in virtually every step of the work: spotting, translation, synchronization, spell check, verification of the maximum number of characters per line, and so on. Users can even install unofficial add-ons to easily check the characterper-second ratio, also called reading time. At the end of the process, the synchronized subtitles can be simulated with the video using the same software.

\section{Technical standards and practices}

One fundamental difference that can be observed in the translation approach used by fansubbers and professional subtitlers involves strategies of text condensation and omission, and minimum reading time. As Table 1 shows, the technical norms adopted by Legendas.tv, the InSUBs team, and also by professional subtitlers are similar in terms of maximum number of lines, maximum line length, and minimum and maximum duration of subtitles. On the other hand, there is a large difference in the maximum character-per- 
BOLD - The Power of Fan Communities...

second ratio used, with fan subtitles requiring considerably more cognitive effort from viewers than subtitles done by professionals.

\begin{tabular}{|l|c|c|c|}
\hline & Legendas.tv & InSUBs team & $\begin{array}{c}\text { Commercial }^{\mathbf{1}} \\
\text { subtitling }^{\mathbf{3}}\end{array}$ \\
\hline Max. number of lines & 2 & 2 & 2 \\
\hline Max. line length & 35 characters & 32 characters & $\begin{array}{c}32 \text { characters or } \\
1,255 \text { pixels }\end{array}$ \\
\hline Min. duration & 1.3 seconds & 1.3 seconds & 1 second \\
\hline Max. duration & not available & 6 seconds & 6 seconds \\
\hline $\begin{array}{l}\text { Max. character-per- } \\
\text { second ratio }\end{array}$ & 23 & $\begin{array}{c}20 \text { (most shows) and } \\
23 \text { (exceptions }\end{array}$ & 15 \\
\hline
\end{tabular}

Table 1: Technical standards according to manuals and style sheets

${ }^{1}$ Source: Lovesick (2010).

${ }^{2}$ Source: Equipe InSUBs (n.d.).

${ }^{3}$ This data has been compiled according to the author's professional experience. Most major Brazilian channels, producers, and distributors do not allow scholars to quote directly from their manuals or style sheets.

${ }^{4}$ The InSUBs manual categorizes these exceptions as (1) shows with over 700 lines in length, (2) comedies, and (3) shows with legal content or comedy-dramas (Equipe InSUBs, n.d., p. 4).

To the best of my knowledge, the only major study carried out to date that addresses technical aspects of Brazilian fansubbing is Marcos Pereira Feitosa's $\mathrm{PhD}$ dissertation (2009). The author analyzes "a corpus comprised of fragments extracted from ten different horror films produced in the current decade in English, with both commercial and fan-made subtitles" (p. 7). Feitosa's study does not address the character-per-second ratio. Nevertheless, one interesting observation is the number of characters per line found in the amateur portion of the corpus: an average of 41.6 characters per line, varying from 34 to 49 (p. 85). This number contrasts greatly with the average he found in the professional counterpart of the corpus: 35 characters per line, a number that is similar to those in Table 1. This data implies that not all Brazilian fansubbers are as concerned with optimal technical parameters as those who belong to the Legendas.tv network. In addition, the higher character-per-line average and higher character-per-second ratio seen in fansubs 
BOLD - The Power of Fan Communities...

suggest that fans in general are less concerned with text reduction, condensation, and omission than professional subtitlers. Feitosa's hypothesis is that fan subtitlers prefer to provide a detailed translation of the audio, even if this strategy makes it more difficult for viewers to read the subtitles without pausing the video (p. 84).

\section{Final remarks}

Despite the impressive popularity of fansubbing in Brazil, no major studies to date have analyzed in depth the linguistic quality of the translations as compared to those of commercial subtitling. One striking difference, however, is clearly seen in the treatment of taboo and colloquial language. Being their own "bosses", fans have the freedom to be as close as possible to the source text register, whereas professionals tend to use more "sanitized" translation alternatives or even omissions (either due to self-censorship or, in most cases, impositions by channels or video producers/distributors).

With the scarcity of research in the area, several questions related to translation quality and viewers' expectations remain unanswered. For instance, what do Brazilian viewers prefer in terms of language register? How much do the fast-paced captions made by fans interfere in the viewers' reception of films? Solid empirical research on the reception of fansubs and commercial subtitles could shed light on some of these issues and perhaps, someday, change the conventions that are today regarded as "best practices" in mainstream subtitling.

Another relevant consequence of the fansubbing phenomenon is that fan communities' sense of immediacy has been pushing the commercial market to deliver translated audiovisual media faster. One particular case is cited by Alice Casarini (2011b, p. 15): "Fox Italy now offers subtitled Glee episodes 48 hours after the US broadcast and a dubbed version a week later". With that in mind, another key question could be posed: how could the commercial audiovisual market better cater to these avid fans without compromising quality? The same author acknowledges that there is room for convergence between amateur and professional subtitling and suggests that a viable solution would be to hire "fans as consultants to speed up dubbing" or to combine "fansubbers' knowledge of shows and American culture with professional AVT [audiovisual translation] skills" (p. $15)$. 
This idea of convergence has also been brought up by Korean scholar Sung-Eun Cho (2011b) and Italian researchers Elena Di Giovanni and Federico Spoletti (2011). According to Cho, a fansubbing contest has been launched in Korea, seeking to integrate the contest's winner into the professional market. Hoping "to lay the foundation for fruitful interchange", Di Giovanni and Spoletti have been carrying out research to "evaluate the possible points of convergence between ever-growing, independent communities and the ever-shrinking, competition-ridden subtitling business", Part of their study has also involved fansubbing contests with prizes that welcome the winners into the professional subtitling world. The researchers hypothesize that the subtitling business is leaning toward convergence: "the joining of forces and competences is probably one of the keys to the enhancement of a business which is undermined by continuous cost reductions and [...] increasing specialisation and technological advances".

At this point, one still cannot estimate the extent to which fansubbing practices will impose changes on the professional market. However, it is clear that the phenomenon is here to stay. Understanding how it works and learning from it seem to be one of the keys to better cater to the well-connected, eager viewership of this century.

\section{Acknowledgments}

I would like to thank Carolina Alfaro de Carvalho and Lynnea Hansen Nascimento for their invaluable insights through revisions and critical reading of this article.

\section{References}

BANDEIRA, A. P. “Don't tell me what I can't do!": as práticas de consumo e participação dos fãs de Lost. Porto Alegre, 2009. 135 p. Thesis (Mestrado em Comunicação Social) - Faculdade de Comunicação Social, Pontifícia Universidade Católica do Rio Grande do Sul. Available at $<$ http://tede.pucrs.br/tde_busca/arquivo.php?codArquivo=2038>. Accessed on Jul. $29,2011$.

BERNARDO, M. H. P. Subtitulando: o universo dos legenders e fansubbers no Brasil. São Paulo, 2011. 114p. Research paper (Pós-graduação lato sensu em Comunicação Social). Faculdade Cásper Líbero. Available at <http://nonameshideout.com/Monografia\%20-\%20Subtitulando.pdf>. Accessed on Jul. 21, 2011. 
BOGUCKI, L. Amateur Subtitling on the Internet. In: DÍAZ CINTAS, J.; ANDERMAN, G. (Eds.). Audiovisual Translation: Language Transfer on Screen. London: Palgrave Macmillan, 2009.

CALAZANS, R. Mercado começa a ver com bons olhos equipes de fãs que legendam séries na internet. O Globo, May 10, 2010. Available at <http://oglobo.globo.com/cultura/mat/2010/05/07/mercado-comeca-ver-com-bonsolhos-equipes-de-fas-que-legendam-series-na-internet-916531486.asp>. Accessed on 21 Jul. 2011.

CASARINI, A. Chorus Lines. Translating Musical TV Series in the Age of Participatory Culture: The case of Glee (Abstract). In: $4^{\text {th }}$ International Conference Media for All - Audiovisual Translation: Taking Stock, Jun. 28-Jul. 1, 2011, London. Programme \& Abstracts. London: Imperial College London, 2011a.

Chorus Lines. Translating Musical TV Series in the Age of Participatory Culture: The case of Glee (Presentation slides). In: $4^{\text {th }}$ International Conference Media for All - Audiovisual Translation: Taking Stock, Jun. 28-Jul. 1, 2011, London, 2011b (Unpublished).

CHO, S. The Two Channels: A Comparison of Amateur and Professional Translations of American TV Sitcoms in the New Media Environment in Korea (Abstract). In: $4^{\text {th }}$ International Conference Media for All - Audiovisual Translation: Taking Stock, Jun. 28-Jul. 1, 2011, London. Programme \& Abstracts. London: Imperial College London, 2011a.

.The Two Channels: A Comparison of Amateur and Professional Translations of American TV Sitcoms in the New Media Environment in Korea (Oral presentation). In: $4^{\text {th }}$ International Conference Media for All - Audiovisual Translation: Taking Stock, Jun. 28-Jul. 1, 2011, London, 2011b (Unpublished).

DEPAlMA, D. A.; KELLY, N. Translation of, for, and by the People: How UserTranslated Content Projects Work in Real Life. Massachusetts: Common Sense Advisory, 2008.

DÍAZ CINTAS, J. Introduction - Audiovisual Translation: An Overview of its Potential. In: (Ed.). New Trends in Audiovisual Translation. Bristol, Buffalo, Toronto: Multilingual Matters, 2009. p.1-18.

Back to the Future in Subtitling. In: MuTra 2005 - Challenges of Multidimensional Translation: Conference Proceedings, Saarbrücken, May 2-6, 2005. <http://www.euroconferences.info/proceedings/2005_Proceedings/2005_DiazCintas _Jorge.pdf>. Accessed on 29 Jul. 2011.

DÍAZ CINTAS, J.; MUÑOZ SÁNCHEZ, P. Fansubs: Audiovisual Translation in an Amateur Environment. The Journal of Specialized Translation, v.6. 2006. Available at <http://www.jostrans.org/issue06/art_diaz_munoz.php>. Accessed on Jul. 28, 2011. 
CINTAS, J.; REMAEL, A. Audiovisual Translation: Subtitling. Manchester, UK; Kinderhook, NY: St. Jerome Publishing, 2007.

DI GIOVANNI, E.; SPOLETTI, F. In Search of a Common Ground: Professional Visibility for Amateur Subtitlers. (Abstract). In: $4^{\text {th }}$ International Conference Media for All Audiovisual Translation: Taking Stock, Jun. 28-Jul. 1, 2011, London. Programme \& Abstracts. London: Imperial College London, 2011.

EQUIPE INSUBS. Da tradução à postagem. Como é o processo? In Subs Tumblr, Nov. 2010. Available at <http://insubs.tumblr.com/post/1498996893/da-traducao-apostagem-como-e-o-processo>. Accessed on Jul 29, 2011.

. Manual de auto-revisão. (n.d.) Unpublished text sent electronically via personal communication by Gugasms on Sep. 19, 2011.

FEITOSA, M. P. Legendagem comercial e legendagem pirata: um estudo comparado. Belo Horizonte, 2009. 162p. Dissertation (Doutorado em Linguística Aplicada). Programa de Pós-Graduação em Estudos Linguísticos, Faculdade de Letras, Universidade Federal de Minas Gerais. Available at <www.letras.ufmg.br/poslin/defesas/743D.pdf>. Accessed on Jul. 21, 2011.

FERRER SIMÓ, M. R. Fansubs y scanlations: la influencia del aficionado en los criterios profesionales. Puentes, v.6, p.27-43. 2005.

FRANCO, E. P. C. Fansubs in Brazil: A Threat or a Challenge? (Abstract). In: ScreenIt 2010, Bologna, Oct. 21-23, 2010. Available at <http://screenit2010.sitlec.unibo.it/EFranco_Abstract.pdf>. Accessed on Jul. 21, 2011.

HILLS, M. Fan Cultures. London: Routledge, 2002.

KAYAHARA, M. The Digital Revolution: DVD Technology and the Possibilities for Audiovisual Translation Studies. The Journal of Specialized Translation, v.3. 2005. Available at <http://www.jostrans.org/issue03/art_kayahara.php>. Accessed on Jul. 28, 2011.

LEONARD, S. Progress against the Law: Anime and Fandom, with the Key to the Globalization of Culture. International Journal of Cultural Studies, v.8, n.3, p.281-305. 2005.

LOVESICK. Conteúdo em destaque: padrões para concessão de destaque de legenda na página principal do site. Legendas.tv, Mar. 15, 2010. Available at <http://forum.legendas.tv>. Accessed on Oct. 3, 2011.

MAZETTI, H. M. Cultura participativa, espetáculo interativo: do "empoderamento" ao engajamento corporativo dos usuários de mídia. Proceedings of the XIV Congresso de Ciências da Comunicação na Região Sudeste, Rio de Janeiro, May 7-9, $2009 . \quad$ Available at <http://www.intercom.org.br/papers/regionais/sudeste2009/resumos/R14-06111.pdf $>$. Accessed on Jul. 21, 2011. 
MILlER, G. Danem-se, bastardos! O Estado de S.Paulo, Oct. 25, 2008. Available at <http://www.estadao.com.br/noticias/suplementos,danem-sebastardos,266483,0.htm>. Accessed on Jul. 21, 2011.

MIZUKAMI, P. N. et al. Brazil. In: KARAGANIS, Joe (Ed.). Media Piracy in Emerging Economies. United States of America: Social Science Research Council, 2011. p. 219-304. Available at <http://hdl.handle.net/10625/46491>. Accessed on Jul. 30, 2011.

O’HAGAN, M. Evolution of User-generated Translation: Fansubs, Translation Hacking and Crowdsourcing. Journal of Internationalisation and Localisation, v.1, n.1, p. 94-121. 2009. Available at <http://pmstrad.com/wpcontent/JIAL_2009_1_2009_APA.pdf>. Accessed on Jul. 21, 2011.

PAGANO, G. Legendadores: por trás dos caracteres que aparecem no vídeo. TeleSéries Magazine, Dec. 14, 2010. Available at <http://teleseries.uol.com.br/legendadoreseles-estao-por-tras-dos-caracteres-que-aparecem-no-video >. Accessed on Jul. 21, 2011.

PÉREZ GONZÁLEZ, L. Fansubbing Anime: Insights into the 'Butterfly Effect' of Globalisation on Audiovisual Translation. Perspectives, v.14, n.4, p.260-277. 2007.

RAMOS, J. S. A. Fansubs: uma análise comparativa das legendas de Lost feitas pela equipe Psicopatas e pela equipe Sci Fi Team. Salvador, 2010. 39p. Research paper (Undergraduate level) - Faculdade de Letras, Universidade Federal da Bahia.

TOFFLER, A.; Toffler, H. Revolutionary Wealth. New York: Alfred A. Knopf, 2006. 492p. 